\section{Proposed Standards for Assessing Language Skills of Adolescent Students}

\author{
Juan Lagos-Luciano ${ }^{a}$, Cynthia Lee Andruske ${ }^{b}$, \\ Marco Cossio-Bolañosc, Jose Sulla-Torres ${ }^{d}$, Leonel Coyla Idme ${ }^{e}$, \\ Cristian Luarte-Rochaf, Rossana Gómez-Camposg, ${ }^{\mathrm{g}}$
}

\begin{tabular}{ll}
\hline Received: & 9 September 2019 \\
Revised: $\quad$ & 6 November 2019 \\
Accepted: & 16 December 2019 \\
ISSN: $1307-9298$ \\
Copyright $@$ IEJEE \\
www.iejee.com
\end{tabular}

DOI: $10.26822 /$ iejee.2019257670

\begin{abstract}
The aim of the study was to validate an instrument and propose standards to measure the language skills of school adolescents. 2270 adolescents (1134 males and 1136 females) in the region of Maule (Chile) was studied. The age range is between 10 to 18 years. The validated instrument has three categories (verbal, paralinguistic and non-verbal) and a total of 26 items. The instrument showed to be valid after the exploratory analysis and Cronbach a (0.86 to 0.88) showed highly reliable values. The LMS method to develop percentiles, let p10, p50 and p90 calculated by age and sex. The instrument measures developed language skills valid and reliable also adopted cutoffs allow diagnose and adolescents by age and sex. These results suggest the use and application of the instrument as an everyday tool in social, cultural and educational contexts.
\end{abstract}

Keywords: Validity, Reliability, Language Skills, Adolescents, School

\section{Introduction}

During secondary education, adolescents need to participate in opportunities that provide curriculum content that develops linguistic skills (Wetherell, Botting, \& Conti-Ramsden, 2007). Therefore, school is a fundamental environment for stimulating and developing communicative skills of adolescents. Many experts share the conviction that good communicative skills are innate and generally are learned intentionally, systematically, and experientially (Silverman et al., 2005; Kurtz et al., 2005). However, these skills tend to diminish over time unless they are remembered and practiced regularly (Junod Perron, Sommer, Louis-Simonet, \& Nendaz, 2015).

School offers children an environment and opportunities to develop linguistic strategies in diverse areas of human knowledge. This involves skills for making friends in school, communicating effectively with family members, fitting in and being successful in school, and participating in the world of work and business (Harris, 1990).

In general, language is a fundamental skill for human existence at all stages of life. Not all children enter school with the same lexical capabilities. These may be a disadvantage academically for some in comparison to the skills of their peers (Beck, McKeown, \& Kucan, 2008; Carmio, Rios, \& Sparks, 2013; Mancilla-Martinez \& Lesaux, 2011). However, it is during the school years where important growth occurs in the number of new vocabulary words individuals acquire. Furthermore, it is during this time that individuals learn to select words appropriate for responding to particular determined situational contexts and even specific speech (Zimmermann, 2013).

On the other hand, the increase in a sedentary lifestyle and the dependence on technology (Nippold, 1998) has generated a growing concern about how complex and sophisticated communicative interactions have become (Brinton et al., 2004). Furthermore, in many cases, these factors may lead to a decrease in social interactions between children, adolescents, and young adults. This may limit the ability to communicate (Brinton et al., 2004), organize sentences (Wetherell et al., 2007), and use body language during the growth and development stage.

Thus, the focus on speaking, language, and communication are fundamental keys to fitting into society (Larson \& McKinley, 2003). Furthermore, they are important for professional development, especially for the process of finding a job (Iksan et al., 2012), achieving professional development, improving social mobility, and confronting future life changes (DfE, 2011).

In this context, during adolescence, cognitive, emotional, and social development are crucial skills for learning and for life. In addition, during this stage, some tasks related to language are developed at school such as control of selective attention, memorization, and problem solving (Hartshorne, 2011). These may contribute to the development of linguistic, verbal, and non-verbal skills respectively.

In general, through linguistic skills for receiving information, individuals process and express personal thoughts. Therefore, linguistic skills influence in a determined way the quality and accuracy of the information individuals receive (García-Álvarez \& Bermello-Ávila, 2017). Thus, adequate acquisition of language emerges as the tool that allows communication, thought development, culture, and personality consolidation. As a consequence, individuals acquire capabilities to observe, converse, and understand. These directly influence other areas of learning, such as, language, science, and including mathematics.

In this sense, the linguistic skills of adolescents are important because lexical knowledge predicts academic achievement, and it plays an essential role in cognitive development (Dockrell \& Messer, 2004). As a result, children with a larger vocabulary have a greater understanding of what they read.

Juan Lagos-Luciano, Department of Diversity and Educational Inclusivity. Catholic University of Maule. Chile. E-mail: jlagos@ucm.cl

${ }^{\circ}$ Cynthia Lee Andruske, Centro de Investigación CINEMAROS, Arequipa, Perú. E-mail: candruske@gmail.com

Marco Cossio-Bolaños, Department of Physical Activity Sciences of the Catholic University of Maule, Talca, Chile.E-mail: mcossio1972@hotmail.com

Jose Sulla-Torres, Universidad Católica Santa María de Arequipa, Arequipa, Perú. E-mail: josullato@hotmail.com

Leonel Coyla Idme, Departamento de Estadística e Informática, Universidad Nacional del Altiplano, Puno, Perú. E-mail: leonelcoyla@hotmail.com

† Cristian Luarte-Rocha, Universidad San Sebastian, Concepción, Chile. E-mail: cristian.luarte@uss.cl

g** Corresponding Author: Rossana Gómez-Campos, Department of Diversity and Educational Inclusivity, Catholic University of Maule, Chile. E-mail: rossaunicamp@gmail.com 
Therefore, good readers acquire a larger vocabulary than less competent readers (Baumann, 2008; Beck, McKeown \& Kucan, 2008; Nippold, 2007). This explains the close relationship that emerges between the quantity of vocabulary words that an individual possess and reading comprehension (Zimmermann, 2013).

Based on this perspective, an instrument is needed that validates the linguistic skills of adolescent students from the Maule Region (Chile). Furthermore, in view of the absence of standards to evaluate linguistic skills, the objective of this study was to validate an instrument based on content and construct validity and propose standards for measuring linguistic skills of adolescent students. This information could help identify and classify adolescents' skills based on age and sex. Furthermore, this information might contribute to controlling the changes produced during intervention programs and/or training inside or outside of school.

\section{Methodology}

\section{Design and sample}

A descriptive cross-sectional study was carried out. The population consisted of 16220 students $(8590$ males and 7630 females). The 2270 student sample (1134 males and $1136 \mathrm{fe}-$ males) was selected through stratified probabilistic sampling that represented a total of $14 \%(\mathrm{Cl}=95 \%)$ from the Maule Region (Chile). Student ages ranged from 10 to 18 years old. Information was collected from 6 public schools (funded municipally). Figure 1 illustrates the characteristics of the sample studied.

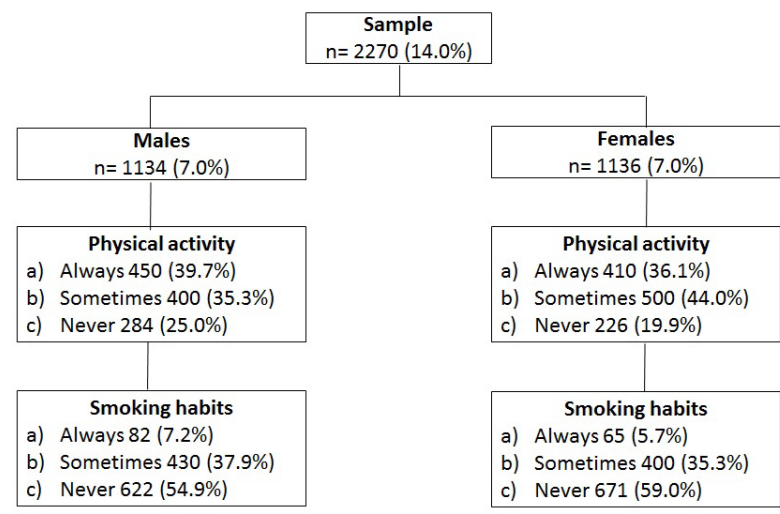

Figure 1. Characteristics of the sample studied

Adolescents included in the study were those in the established age range and those registered in public schools. Students not returning informed consent forms were excluded from the study as well as those not completing correctly the instrument under review. All students participating in the study provided informed consent. In addition, the local ethics committee approved the project in keeping with the Declaration of Helsinki.

\section{Procedures}

The instrument was designed based on the operationalization of the linguistic skills variable. This variable is composed of three categories: verbal, linguistic, and non-verbal skills (appendix 1). Each one of these is represented by a set of questions that are related to content validity (Cossio-Bolaños, 2015). The alternatives for each question were based on the Likert format: a) totally agree, b) neither agree or disagree, and c) totally disagree

Once the instrument was created, the contents were examined by content experts. Then, construct validity was carried out by means of exploratory factorial analysis, EFA.

\section{Validity and reliability of the instrument}

The instrument was validated by two methods: content and construct validity. Content validity was carried out by following Wierseman's (2001) suggestions for the experts' judgement method. Six expert judges were contacted (professional researchers from communications and linguistics) to perform by content, using a scale.

A file was created for the experts so that they could assess the degree of representativeness, relevance, clarity, simplicity, and comprehensibility of the items from the instrument. The experts evaluated the items based on a scale of 1 to 5 points for each item (equivalent to values for not important to very important). During the analysis, adequacy of the item from the instrument developed was accepted with values greater than the $V$ of Aiken $\geq .75$ (Bulger \& Housner, 2007). The means of contacting the experts was by email, and the file for assessing the instrument was also sent to them by email. Initially, the instrument consisted of 36 linguistic skills questions with three categories. At the end of the analysis, the questions were reduced to 26 while maintaining the three categories.

Construct validity for the instrument was carried out by means of the exploratory factorial analysis EFA (Días de Rada, 2002). EFA was used to determine the dimensions of the scale (Fahretdin-Hasan, Seda, \& Engin Ader, 2015) using the principal component analysis (PCA) with Varimax rotation. In addition, the Bartlett's Test of Sphericity and Kaiser-MeyerOlkin (KMO) were applied to determine sampling adequacy for factor analysis.

To verify the reliability of the instrument, internal consistency was analyzed using the Cronbanch coefficient (Cronbach's a). The cut-off points of the instrument were determined by using percentiles. Low skill was identified as $<\mathrm{p} 10$, moderate skill as p10 to p90, and high skill as >p90.

\section{Statistical analysis}

All data was analyzed using the Kolmogorov-Smirnov test. The normality of the data was verified. Subsequently, arithmetic mean descriptive statistics, standard deviation, range, and percentage were carried out. Differences between both sexes were verified by means of the $t$-test for independent samples. Content validity was determined by the $\mathrm{V}$ of Aiken test (Penfield \& Giacobbi, 2004). Construct validity of the instrument was determined by exploratory factorial analysis (EFA). The technique of principal component extraction, Varimax rotation, Kaiser-Meier-Olkin (KMO), Bartlett's Test of Sphericity and percentage variance were carried out. For reliability, Cronbach's alpha was used. Smoothed distribution of percentiles was created by using the LMS method (Cole et al., 2000). Percentiles p10, p50, and p90 were calculated. This procedure allowed standardization of the data for each sex. Furthermore, transformation of the power of Box-Cox was calculated. The maximum penalty probability procedure was run in order to create three new smoothed curves: $L(t)$ Box-Cox Power, $\mathrm{M}(\mathrm{t})$ median, and $\mathrm{S}(\mathrm{t})$ coefficient of variation. The calculations were carried out using LMS Chartmaker Pro Version 2.3 software. All calculations were calculated on Excel sheets and with SPSS 18.0

Results

With regard to content validity, the values from the $V$ of Aiken test are illustrated in Table 1. The values of the V Aiken test for each question oscillate from .75 to 1.0 while for categories these values range from .77 to .94. In all cases, the values from the expert judges reflected an acceptable agreement. The questions that were eliminated showed values inferior to .74 (10 questions) resulting in a final total of 26 questions. 
Table 1. Content validity of the instrument created to measure linguistic skills with the Aiken by question and categories

\begin{tabular}{|c|c|c|c|c|c|c|c|}
\hline $\mathbf{N}^{\circ}$ & Items/ categories & Representativeness & Relevance & Clarity & Simplicity & Comprehensibility & Total \\
\hline 1 & Item 1 & 1.00 & .75 & 1.00 & .86 & 1.00 & .92 \\
\hline 2 & Item 2 & .93 & 93 & .93 & .93 & .93 & .93 \\
\hline 3 & Item 3 & 1.00 & .96 & .86 & .82 & .86 & .90 \\
\hline 4 & Item 4 & 1.00 & .82 & .93 & 1.00 & .75 & .90 \\
\hline 5 & Item 5 & .93 & 1.00 & .93 & .93 & .96 & .95 \\
\hline 6 & Item 6 & .75 & .93 & .86 & .75 & .86 & .83 \\
\hline 7 & Item 7 & .96 & .86 & .75 & .88 & .89 & .87 \\
\hline 8 & Item 8 & .86 & .75 & .96 & .75 & .82 & .83 \\
\hline 9 & Item 9 & .93 & .96 & .86 & .96 & 1.00 & .94 \\
\hline 10 & Item 10 & .82 & .86 & .89 & .86 & .93 & .87 \\
\hline 11 & Item 11 & .89 & .85 & .88 & .88 & .90 & .88 \\
\hline 12 & Item 12 & 1.00 & .75 & .86 & .75 & .75 & .82 \\
\hline 13 & Item 13 & .93 & .96 & .75 & .82 & .96 & .88 \\
\hline Verbal category & & .92 & .88 & .88 & .86 & .89 & .89 \\
\hline 14 & Item 14 & .86 & .75 & .75 & 1.00 & .86 & .84 \\
\hline 15 & Item 15 & 1.00 & .88 & .75 & .75 & .93 & .86 \\
\hline 16 & Item 16 & .93 & .75 & .93 & .88 & .86 & .87 \\
\hline 17 & Item 17 & .75 & .96 & .93 & .75 & .75 & .83 \\
\hline 18 & Item 18 & .96 & .86 & .86 & .96 & .96 & .92 \\
\hline 19 & Item 19 & .86 & .96 & .86 & .86 & .75 & .86 \\
\hline 20 & Item 20 & .75 & .86 & .86 & .93 & .75 & .83 \\
\hline 21 & Item 21 & .75 & .75 & .86 & .93 & .93 & .84 \\
\hline 22 & Item 22 & .93 & .96 & .86 & 1.00 & 1.00 & .95 \\
\hline Linguistic category & & .87 & .86 & .85 & .90 & .87 & .87 \\
\hline 23 & Item 23 & .86 & .75 & .86 & .93 & .75 & .83 \\
\hline 24 & Item 24 & .75 & .96 & .86 & .75 & .96 & .86 \\
\hline 25 & Item 25 & .96 & .93 & .75 & .96 & .75 & .87 \\
\hline 26 & Item 26 & .86 & .82 & .96 & .96 & .96 & .91 \\
\hline Non-verbal category & & .86 & .87 & .86 & .90 & .86 & .87 \\
\hline
\end{tabular}

The results of the construct validity and reliability are shown in Figure 2. The saturation of the three categories vary between .350 to .822 . The percentage of explanation of the variance of the instrument is $53 \%$ (36.0\% verbal skill, $9.0 \%$ paralinguistic skill, and $8 / 0 \%$ non-verbal skill). The Cronbach values showed reliability in each of the questions ( $\alpha=.86$ to $.88)$ and in the entire instrument $(\alpha=.87)$.

The values for the linguistic skills are represented in percentiles in Table 2. The assessment was carried out for each category (verbal, linguistic, and non-verbal) and for the entire instrument. The percentiles for both are as follows: p10, p50, and p90. The calculations may be interpreted as a function of age and sex. Figure 3 illustrates the graph for percentiles.

\section{Discussion}

The instrument created for this study consisted of three categories to measure the verbal, paralinguistic, and nonverbal skills. These skills, in general, are interpreted by the receiver and/or receivers through clarity, coherence, and voice intonation in addition to body, facial, and posture expressions. These expressions may vary greatly. Furthermore, they may change the significance of the statement according to the receptor (Stiff et al., 1990) and the circumstances.

The results of this study have demonstrated that the instrument proposed to measure linguistic skills of adolescent students is valid for content and construct (EFA). Based on the analysis of the content by expert judges, the V Aiken test values obtained in this study were valid for 26 questions. These findings reflect homogeneity between six judges. They found representativeness, relevance, clarity, simplicity, and comprehensibility as suggested by Wierseman (2001).

The findings obtained from this research are similar to reports with the same type of characteristics (García \& Garcia, 2014; Bolivar-Paredes et al., 2017; Martin-Romera \& Molina, 2017). These ensure an adequate measurement of psychometric properties from expert judges. However, it is necessary to compare the results with other validation theories to ensure quality control for other psychometric properties (Kane, 2009). Consequently, a second technique to validate the instrument was the EFA, used to assess the 26 questions validated previously by content.

The results showed greater saturation than 3.50 for all of the questions. These results guaranteed the validity of the instrument since studies with similar statistical analyses, but with different techniques, have reported slightly higher values (Iglesias, 2009; Jaramillo \& Ossesa, 2012; CossioBolaños et al., 2013). Therefore, the instrument created for this study is valid and allows the accurate assessment of the linguistic skills of adolescents of both sexes.

With regard to the reliability of the instrument, which guarantees quality control, Cronbach's a values were highly 


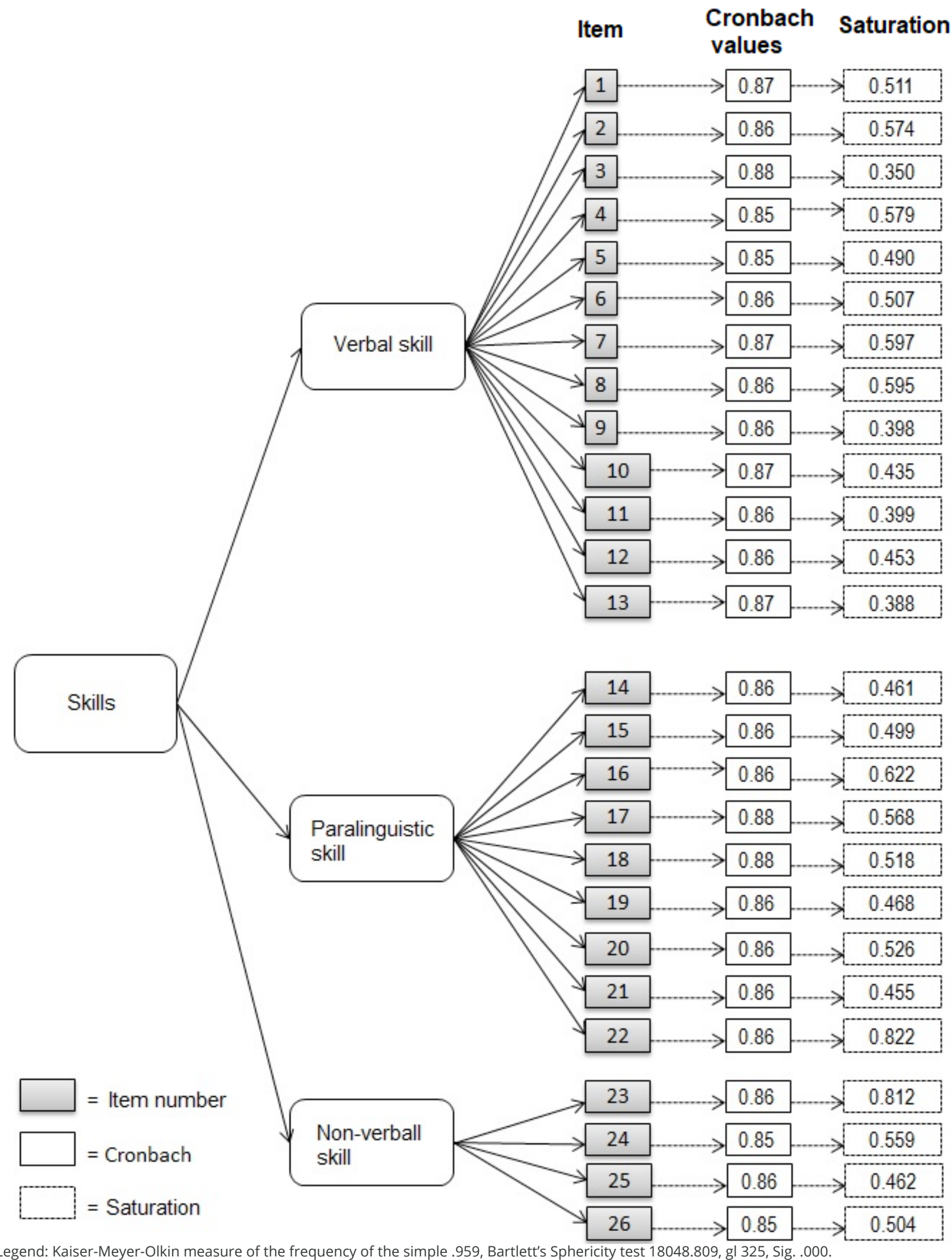

Figure 2. Reliability and Cronbach's a values for validity and reliability of the instrument created 
Table 2. Percentile distribution of linguistic skills for adolescents by age and sex

\begin{tabular}{|c|c|c|c|c|c|c|c|c|c|c|c|c|c|c|}
\hline \multirow{2}{*}{ Age (years) } & \multirow{2}{*}{ N } & \multicolumn{6}{|c|}{ Males ( $n=1134)$} & \multirow{2}{*}{ N } & \multicolumn{6}{|c|}{ Females $(n=1136)$} \\
\hline & & $\mathrm{L}$ & $M$ & $\mathrm{~s}$ & P10 & P50 & P90 & & $L$ & M & $\mathrm{s}$ & P10 & P50 & P90 \\
\hline & & \multicolumn{13}{|c|}{ Verbal skill } \\
\hline 10 & 68 & 2.91 & 28.46 & .10 & 24.2 & 28.5 & 31.8 & 76 & 2.55 & 27.87 & .12 & 22.7 & 27.9 & 31.9 \\
\hline 11 & 124 & 1.66 & 28.17 & .11 & 24.1 & 28.2 & 31.9 & 121 & 1.76 & 28.01 & .12 & 23.3 & 28.0 & 32,2 \\
\hline 12 & 165 & .40 & 28.07 & .12 & 24.1 & 28.1 & 32.4 & 196 & .93 & 27.79 & .12 & 23.5 & 27.8 & $32, .1$ \\
\hline 13 & 161 & -.77 & 27.76 & .12 & 23.9 & 27.8 & 32.9 & 185 & .08 & 27.67 & .12 & 23.6 & 27.7 & 32.4 \\
\hline 14 & 173 & -1.73 & 27.40 & .13 & 23.6 & 27.4 & 33.6 & 156 & -.52 & 27.83 & .13 & 23.8 & 27.8 & 32.9 \\
\hline 15 & 184 & -2.12 & 27.06 & .14 & 23.2 & 27.1 & 33.9 & 135 & -.73 & 27.82 & .13 & 23.8 & 27.8 & 33.2 \\
\hline 16 & 134 & -1.62 & 26.72 & .14 & 22.7 & 26.7 & 33.2 & 115 & -.61 & 27.37 & ,13 & 23.3 & 27.4 & 32.8 \\
\hline 17 & 66 & -.68 & 26.73 & .15 & 22.4 & 26.7 & 32.6 & 85 & -.41 & 27.10 & 13 & 23.0 & 27.1 & 32.4 \\
\hline \multirow[t]{2}{*}{18} & 59 & .37 & 26.72 & .15 & 22.0 & 26.7 & 32.0 & 67 & -.21 & 26.75 & ,13 & 22.6 & 26.7 & 31.9 \\
\hline & & \multicolumn{13}{|c|}{ Paralinguistic skill } \\
\hline 10 & 68 & 1.81 & 19.72 & .14 & 15.9 & 19.7 & 23.0 & 76 & 1.22 & 20.05 & .16 & 16.0 & 20.1 & 24.0 \\
\hline 11 & 124 & 1.49 & 19.32 & .14 & 15.7 & 19.3 & 22.6 & 121 & 1.37 & 19.55 & .16 & 15.5 & 19.6 & 23.3 \\
\hline 12 & 165 & 1.19 & 19.11 & .14 & 15.7 & 19.1 & 22.4 & 196 & 1.47 & 19.00 & .16 & 15.0 & 19.0 & 22.7 \\
\hline 13 & 161 & 1.01 & 18.91 & .14 & 15.6 & 18.9 & 22.2 & 185 & 1.45 & 18.81 & .16 & 14.8 & 18.8 & 22.5 \\
\hline 14 & 173 & .87 & 18.66 & .14 & 15.4 & 18.7 & 22.0 & 156 & 1.39 & 18.89 & .16 & 14.9 & 18.9 & 22.6 \\
\hline 15 & 184 & .59 & 18.43 & .14 & 15.2 & 18.4 & 21.9 & 135 & 1.31 & 18.89 & .16 & 14.9 & 18.9 & 22.6 \\
\hline 16 & 134 & .01 & 18.32 & 15 & 15.1 & 18.3 & 22.2 & 115 & 1.23 & 18.70 & .16 & 14.9 & 18.7 & 22.4 \\
\hline 17 & 66 & -.92 & 18.17 & .16 & 15.1 & 18.2 & 22.7 & 85 & 1.12 & 18.70 & .15 & 15.0 & 18.7 & 22.3 \\
\hline \multirow[t]{2}{*}{18} & 59 & -2.11 & 17.84 & .17 & 15.0 & 17.8 & 23.7 & 67 & 1.02 & 18.65 & .15 & 15.1 & 18.7 & 22.2 \\
\hline & & \multicolumn{13}{|c|}{ Non-verbal skill } \\
\hline 10 & 68 & .63 & 8.73 & .14 & 7.2 & 8.7 & 10.4 & 76 & .02 & 8.42 & .15 & 7.0 & 8.4 & 10.2 \\
\hline 11 & 124 & .72 & 8.62 & .15 & 7.1 & 8.6 & 10.3 & 121 & .03 & 8.58 & .15 & 7.0 & 8.6 & 10.4 \\
\hline 12 & 165 & .82 & 8.55 & .15 & 6.9 & 8.6 & 10.2 & 196 & .60 & 8.55 & .16 & 6.9 & 8.5 & 10.4 \\
\hline 13 & 161 & .94 & 8.58 & .16 & 6.8 & 8.6 & 10.3 & 185 & .84 & 8.49 & .17 & 6.7 & 8.5 & 10.3 \\
\hline 14 & 173 & 1.06 & 8.54 & .17 & 6.7 & 8.5 & 10.3 & 156 & .98 & 8.54 & .17 & 6.7 & 8.5 & 10.4 \\
\hline 15 & 184 & 1.13 & 8.47 & .17 & 6.6 & 8.5 & 10.3 & 135 & 1.05 & 8.64 & .18 & 6.7 & 8.6 & 10.6 \\
\hline 16 & 134 & 1.07 & 8.49 & .17 & 6.6 & 8.5 & 10.3 & 115 & 1.15 & 8.53 & .18 & 6.6 & 8.5 & 10.4 \\
\hline 17 & 66 & .83 & 8.53 & .17 & 6.7 & 8.5 & 10.4 & 85 & 1.23 & 8.34 & .18 & 6.4 & 8.3 & 10.2 \\
\hline \multirow[t]{2}{*}{18} & 59 & .53 & 8.48 & .17 & 6.7 & 8.5 & 10.4 & 67 & 1.29 & 8.10 & .18 & 6.2 & 8.1 & 9.9 \\
\hline & & \multicolumn{13}{|c|}{ Linguistic skills (Total) } \\
\hline 10 & 68 & 1.31 & 56.84 & .10 & 49.8 & 56.8 & 63.6 & 76 & -.93 & 57.39 & -1.00 & 46.0 & 57.4 & 65.2 \\
\hline 11 & 124 & .89 & 55.94 & .10 & 49.0 & 55.9 & $62 / 9$ & 121 & -.95 & 56.60 & -1.00 & 46.6 & 56.6 & 64.4 \\
\hline 12 & 165 & .50 & 55.66 & .10 & 48.8 & 55.7 & 63.0 & 196 & -.97 & 55.56 & -1.00 & 46.6 & 55.6 & 63.5 \\
\hline 13 & 161 & .23 & 55.40 & .10 & 48.5 & 55.4 & 63.1 & 185 & -.99 & 55.13 & -1.00 & 46.9 & 55.1 & 63.4 \\
\hline 14 & 173 & .07 & 54.91 & .11 & 47.8 & 54.9 & 63.0 & 156 & -1.01 & 55.35 & -1.00 & 47.4 & 55.3 & 64.1 \\
\hline 15 & 184 & -.07 & 54.30 & .11 & 47.0 & 54.3 & 62.8 & 135 & -1.02 & 55.31 & -1.00 & 47.4 & 55.3 & 64.6 \\
\hline 16 & 134 & -.28 & 53.92 & .12 & 46.5 & 53.9 & 63.0 & 115 & $\begin{array}{l}-1.03 \\
\end{array}$ & 54.40 & -1.00 & 46.6 & 54.4 & 64.0 \\
\hline 17 & 66 & -.73 & 5399 & .13 & 46.3 & 54.0 & 64.1 & 85 & -1.03 & 53.95 & -1.00 & 46.3 & 54.0 & 63.6 \\
\hline 18 & 59 & -1.40 & 53.88 & .14 & 46.1 & 53.9 & 65.7 & 67 & -1.04 & 53.61 & -1.00 & 46.1 & 53.6 & 63.3 \\
\hline
\end{tabular}

Legend: L= assymetry; M= median; $\mathrm{S}=$ coefficient of variation.
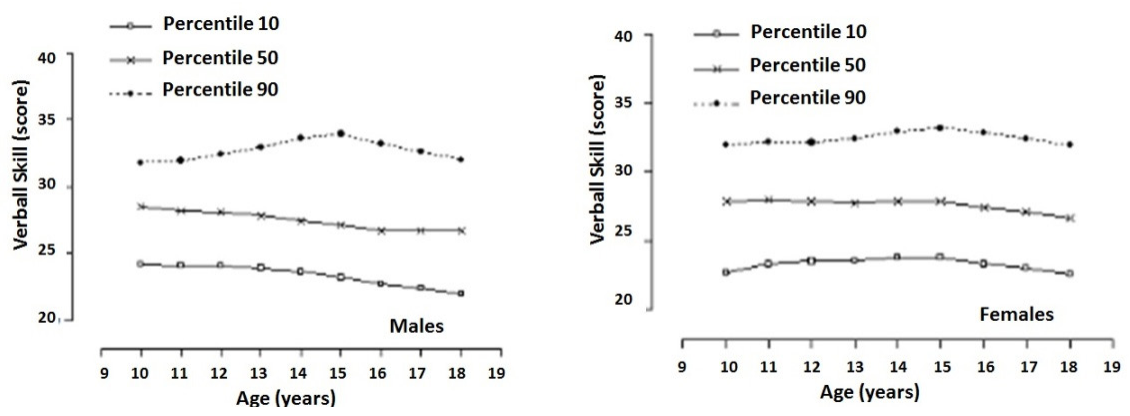

Figure 3. Graph of the percentiles based on the LMS method, distributed in p10, p50, and p90 by age and sex 

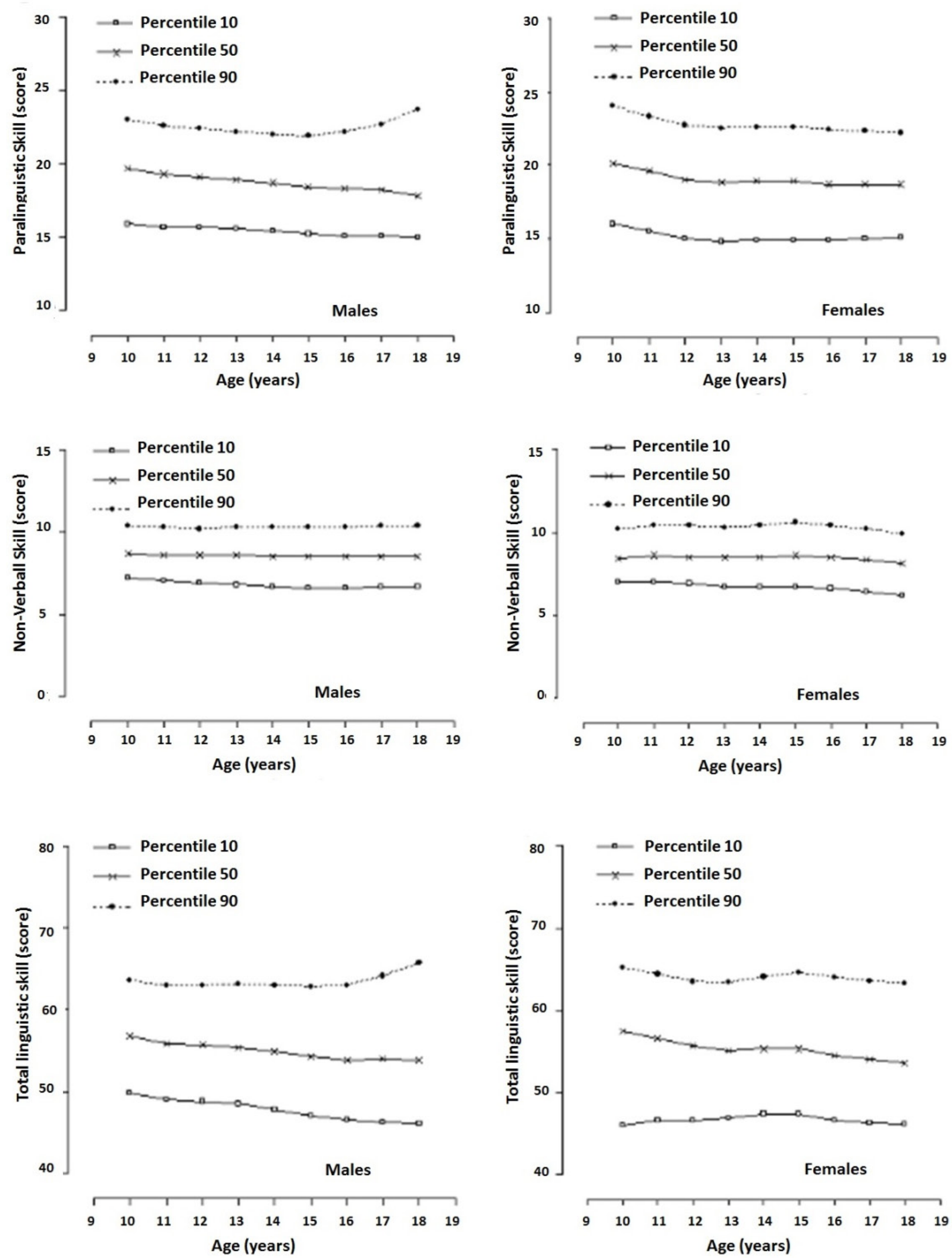

Figure 3 (Cont.). Graph of the percentiles based on the LMS method, distributed in p10, p50, and p90 by age and sex. 
reliable. These findings are consistent with other studies with similar objectives (Cossio-Bolaños, Andruske, VargasVitoria, Lagos-Luciano, Luarte-Rocha, Sulla-Torres, \& GómezCampos, 2019; Cossio-Bolaños, Monné, Cornejo, Lepe, Vidal, \& Araújo, 2013; Dini, Alves, Oliveira, \& Guirardello, 2014).

In general, the conscious development of verbal, paralinguistic, and non-verbal skills may be crucial for improving the communicative capacity with others. Thus, the non-verbal skills are defined as the facial expressions and looking into the eyes of others. These expressions provide a rich source of non-verbal information, especially in transmitting emotions from the sender (Dixon \& O'Hara, 2008). However, the term paralinguistic refers to characteristics such as speaking speed, tone, pronunciation, pausing, and emphasizing voice modulation that reflect happiness and/or sadness. However, these paralinguistic signs are difficult to decipher and are generally ambiguous.

Verbal skills include knowing how to listen, speak, read, and write. These skills are represented by the use of concrete and abstract vocabulary and meanings embedded in sentences by going through formal phonological and morphosyncratic structures. Additionally, practical aspects are also established that are necessary for verbal and social interaction, respectively (Dixon \& O'Hara, 2008).

In essence, the instrument created actually measures the three categories described previously. Therefore, the exploratory analysis allowed us to corroborate that the questions formulated for each category were relevant. This instrument may be useful for educators as well as researchers since the three categories for the skills may be operationalized and may serve to measure the performance of linguistic skills. Consequently, they may perform a relevant role in academic success (Uccelli et al., 2014), not only during the school years but also at the university level.

With regard to the proposed norms to evaluate the linguistic skills, this researchers used the LMS method (Cole et al., 2000) to develop the percentiles. The three parameters, $(\mathrm{L}(\mathrm{t})$ Box-Cox power, $\mathrm{M}(\mathrm{t})$ median, and $\mathrm{S}(\mathrm{t})$ Coefficient of variation) allowed the creation of the curves in relation to any percentile using LMS (Pan \& Cole, 2006). This guarantees that the extremes of the percentiles may be estimated more efficiently, and each observation may be converted into its standard deviation (Kulaga et al., 2011).

In this context, the cut-off points adopted $(<\mathrm{p} 10$, between p10 to p90 and >p90) allowed identifying, classifying, and diagnosing the linguistic skills of the adolescents. This academic tool is relevant for monitoring and following adolescents during the teaching-learning process throughout the school years. Therefore, linguistic skills are still developing during adolescence and potentially throughout the lifetime. In addition, users of daily language develop new sills in order to navigate a growing number of social contexts (Berman \& Ravid, 2009).

Generally, the studies that focus on linguistic skills have suggested that students need to be evaluated during oral presentations continually in order to become confident, use actual technologies, capable of initiating and sustaining a discussion, accepting of criticism, and capable of making concise conclusions during discussions (Adler, Werner, \& Korsch, 1980; Fann, Hunt, \& Schaad, 2003). In this sense, the proposed instrument is an alternative that allows students to maintain personal motivation to practice, stimulate, and compare the student with himself or herself as well as with others.

It is necessary to point out that this study has some limitation. For example, the data collection was transversal, and it was carried out only in public (municipal) schools.
Therefore, future studies need to include private schools in the evaluation process. This would have provided relevant information to analyze and interpret more accurately the results obtained. However, at the time of the research, more funding would have been required and difficulty in collecting information would have occurred. This research only examined state public schools (municipal). Moreover, it is necessary to highlight advantages of this study such as the large sample size and the ease of carrying out the calculations in real time. Thus, the assessment of the linguistic skills may be carried out with the following link: http://www.reidebihu.net/ling_skill.php

\section{Conclusion}

The researchers conclude that the instrument created measures the linguistic skills validly and reliably for content as well as for EFA. Furthermore, the cut-off-points adopted allow diagnosis and classification of adolescents according to age and sex. Finally, the results from this study suggest the use and implementation of this instrument could be used as a daily tool in social, cultural and educational contexts.

\section{Acknowledgements}

The authors wish to thank the teachers and students from the participating schools.

\section{Disclosure statement}

The authors reported no potential conflict of interest.

\section{References}

Adler, R., Werner, ER. \& Korsch, B. (1980). Systematic study of four years of internship. Pediatrics, 66(6):1000-8.

Baumann, J.F. (2008). Vocabulary and reading comprehension: the nexus of meaning. En S. E. Israel \& G. G. Duffy (Eds.), Handbook of Research on Reading Comprehension, 32334. Nueva York: Routledge.

Beck, I.L., McKeown, M.G. \& Kucan, L. (2008). Creating Robust Vocabulary. Nueva York: The Guilford Press.

Berman, R.A. \& Ravid, D. (2009). Becoming a literate language user: Oral and written text construction across adolescence. In D. R. Olson, \& N. Torrance (Eds.), Cambridge handbook of literacy (pp. 92-111). Cambridge, UK: Cambridge University Press.

Brinton, B., Robinson, LA. \& Fujiki, M. (2004). Description of a program for social language intervention: If you can have a conversation, you can have a relationship. Language, speech and Hearing Services in School, 35(3):283290.

Bolivar-Paredes, E. \& Villanueva-Ruska, A. (2017). Validación y confiabilidad del Cuestionario AQ-27 de actitudes estigmatizadoras hacia pacientes con esquizofrenia en un Hospital General-2015. Revista de Neuro-Psiquiatría, 80(3), 165-171.

Bulger, S.M., \& Hourner, L.D. (2007). Modified delphi investigation of exercise science in physical education teacher education. Journal of Teaching in Physical Education, 26, 57-80.

Carmiol, A., Ríos, M. \& Sparks, A. (2013). La relación entre habilidades prelectoras y habilidades narrativas en niños y niñas preescolares costarricenses: aportes para un enfoque comprensivo de la alfabetización emergente. En A. Auza \& K. Hess (Eds.), ¿Qué me cuentas? Narraciones y desarrollo lingüístico en niños hispanohablantes. México: Universidad Autónoma de Querétaro-Hospital Dr. Manuel Gea González. 
Cole, TJ., Bellizzi, MC., Flegal, KM. \& Dietz, WH. (2000). Establishing a standard definition for child overweight and obesity worldwide: international survey. $B M J$, 320(7244):1240-3.

Cossio-Bolaños M., Andruske, CL., Vargas-Vitoria, R., Lagos-Luciano, J., Luarte-Rocha, C., Sulla-Torres, J. \& Gómez-Campos, R. (2019). Validation of an Instrument to Assess the Skill Levels of Adolescent Students to Learn Knowledge. International Electronic Journal of Elementary Education, 12(1), 47-52.

Cossio-Bolaños, MA. (2015). Métodos de investigación cuantitativa en ciencias de la educación. Editorial UCM, Talca, Chile.

Cossio-Bolaños, MA., Monné, R., Cornejo, C., Lepe, N., Vidal, R. \& Araújo, P. (2013). Construcción de un instrumento para medir el uso del conocimiento científico en alumnos de educación especial y psicopedagogía. Multiciencias, 13(1), 68-74.

DfE (2011) Opening Door, breaking down barriers: a strategy for social mobility. HM Government, London SW1A 2WH.https://www.gov.uk/government/uploads/ system/uploads/attachment_data/file/61964/opening-doors-breaking-barriers.pdf

Díaz de Rada Igurquiza, V. (2002). Análisis Factorial. En: Díaz de Rada Igurquiza V. Técnicas de análisis multivariante para investigación social y comercial. Madrid: RA-MA. 91-156.

Dini, A., Alves, DF., Oliveira, H. \& Guirardello, E. (2014). Validez y confiabilidad de un instrumento de clasificación de pacientes pediátricos. Rev. Latino-Am. Enfermagem, 22(4), 598-603. DOI: 10.1590/0104-1169.3575.2457

Dixon, T. \& O'Hara, M. (2008). Making Practice-Based Learning work - Communication Skills. (Accessed: 11/06/2013): http://cw.routledge.com/textbooks/9780415537902/ data/learning/11_Communication\%20Skills.pdf

Dockrell, J. \& Messer, D. (2004). Lexical acquisition in the early school years. En R. A. Berman (Ed.), Language Development Across Childhood and Adolescence, 35-52. Amsterdam-Philadelphia: John Benjamins.

Fahretdin-Hasan, A., Seda S. \& Engin A. (2015). Assessing Preschool Teachers' Practices to Promote Self-Regulated Learning. International Electronic Journal of Elementary Education, 7(3), 423-440

Fann, JR., Hunt, DD. \& Schaad, D. (2003). A sociological calendar of transitional stages during psychiatry residency training. Acad Psychiatry, 27(1):31-8.

García, M.A. \& García, M. (2013). Estimación de la validez de contenido en una escala de valoración de grado de violencia de género soportado en adolescentes. Acción Psicológica, 10(2), 41-58.

García-Álvarez, C.M. \& Bermello-Ávila, C.B. (2017). Habilidades lingüísticas en la comprensión lectora en los estudiantes de quinto grado de subnivel medio de la Escuela de Educación Básica Eugenio Espejo, periodo lectivo 2016-2017(BacheIor's thesis, Universidad de Guayaquil. Facultad de Filosofiía, Letras y Ciencias de la Educación.).

Guttman-Louis. (1976). Fundamentos del análisis del escalograma. En: Wainerman $\mathrm{CH}$ (comp). Escalas de medición en ciencias sociales. Buenos Aires. Ediciones Nueva Visión, 291-330.
Hartshorne M. I CAN Talk is a series of reports exploring contemporary issues in children's speech, language and communication. London, 2011. www.ican.org.uk

Iglesias, MJ. (2009). Elaboración y validación de un instrumento diagnóstico para la percepción de las competencias emocionales en estudiantes universitarios de educación. REOP, 20(3), 300-311.

Iksana ZH., Zakaria E., Meerah, TS., Osman, K., Choon-Liana, DK., Mahmud, SN. \& Krish, P. (2012). Communication skills among university students. Procedia-Social and Behavioral Sciences, 59, 71 - 76.

Jaramillo, S. \& Ossesa, S. (2012). Validación de un Instrumento sobre Metacognición para Estudiantes de Segundo Ciclo de Educación General Básica. Estudios Pedagógicos, 38(2), 117-131.

Kułaga, Z., Litwin, M., Tkaczyk, M., Palczewska, I., Zajączkowska, M., Zwolinska, D., Krynicki, T., Wasilewska, A., Moczulska, A., Morawiec-Knysak, A., Barwicka, K., Grajda, A., Gurzkowska, B., Napieralska, E., \& Pan, H. (2011). Polish 2010 growth references for school-aged children and adolescents. Eur J Pediatr, 170, 599-609.

Kurtz, S., Silverman, J. \& Draper, J. (2005). Teaching and learning communication skills in medicine. 2nd edition. Oxford: Radcliff Publishing Ltd.

Larson, VL. \& McKinley, NL. (2003). Service Delivery Options for Secondary Students with Language Disorders. Seminars, Speech and Language, 24(3).

Mancilla-Martínez, J. \& Lesaux, N. K. (2011). Early home language use and later vocabulary development. Journal of Educational Psychology, Advance online publication. doi: 10.1037/a0023655.

Martin-Romera, A. \& Molina Ruiz, E. (2017). Valor del conocimiento pedagógico para la docencia en Educación Secundaria: diseño y validación de un cuestionario. Estudios pedagógicos (Valdivia), 43(2), 195-220.

Nippold, M. (2007). Later Language Development: School-Age Children, Adolescents, and Young Adults. Austin TX: Pro-Ed.

Nippold, MA. (1998). Later Language Development: The school age and adolescent years. (2nd ed.). Austin, TX: Pro-Ed.

Nippold, MA. (2007). Later language development: school-age children, adolescents, and young adults (3rd ed). Austin, Texas PRO-ED.

Pan, H. \& Cole, TJ. LMS Chartmaker. 2006. http://www.healthforallchildren.co.uk, accessed 11 march 2012.

Perron, NJ., Sommer, J., Louis-Simonet, M. \& Nendaz, M. (2015). Teaching communication skills: beyond wishful thinking. Swiss Med Wkly, 145, 1-10, w14064

Penfield, R.D. \& Giacobbi, P.R. (2004). Applying a score confidence interval to Aiken's item contentrelevance index. Measurement in Physical Education and Exercise Science, 8(4), 213-225.

Silverman, J., Kurtz, S. \& Draper, J. (2005). Skills for communicating with patients. 2nd edition. Oxon: Radcliff Publishing Ltd.

Stiff, J.B., Hale, J.L., Garlic, R. \& Rogan, R. G. (1990). Effect of cue incongruence and social normative influences on individual judgments of honesty and deceit. Southern Communication Journal, 55, 206-229. 
Uccelli, P., Barr, CD., Dobbs, CL., Galloway, EP., Meneses, A. \& Sanchez, E. (2014). Core Academic Language Skills (CALS): An expanded operational construct and a novel instrument to chart school-relevant language proficiency in per-adolescent and adolescent learners. Applied Psycholinguistics, 1-33.

Wetherall, D., Botting, N. \& Conti-Ramsden, G. (2007). Narrative in adolescent specific language impairment (SLI): a comparison with peers across two different narrative genres. International Journal of language and communication disorders, 42(5), 583-605.

Wierseman, L.D. (2001). Conceptualization and development of the sources of enjoyment in youth sport questionnaire. Measurement in Physical Education and Exercis escience, 5(3), 153-157.

Zimmermann, K. (2013). Desarrollo léxico en la adolescencia: Un análisis de sustantivos en narraciones orales y escritas. Actualidades en psicología, 27(115), 113-127. 


\section{Appendix \\ Validation of linguistic skills}

Dear Student, the purpose of this questionnaire is to collect information about linguistic skills. Please mark with an X the answer that you consider fits you best. Please select only one answer. Thank you for your help in answering these questions.

Date of assessment: Day ( ), Month ( ), Year ( ) ); Sex: (M) / (F); Birth date: Day ( ), Month ( ), Year ( ) Participation in physical activities: Always（）, Sometimes（）, Never（）. Smoking: Always（）, Sometimes（）, Never（）.

\begin{tabular}{|c|c|c|c|c|c|c|}
\hline Questions & & & NDA & -NED & T & \\
\hline 1. I have a large vocabulary. & ( & ) & ( & ) & ( & ) \\
\hline 2. I establish a mutual dialogue and share common themes of interest for me and my speaking partner. & ( & ) & ( & ) & ( & ) \\
\hline 3. Frequently, I worry about having to speak in public. & ( & ) & ( & ) & ( & ) \\
\hline 4. In general, it is difficult for me to maintain control of conversations. & ( & ) & ( & ) & ( & ) \\
\hline 5. I feel that others enjoy speaking with me. & ( & ) & ( & ) & ( & \\
\hline 6. Often, I consider my conversations are successful. & ( & ) & ( & ) & ( & \\
\hline 7. I have the skill to speak with clarity. & ( & ) & ( & ) & ( & \\
\hline 8. Frequently, family members or friends ask me to speak for them because I am a good speaker. & ( & ) & ( & ) & ( & \\
\hline 9. Generally, I speak very fats, and sometimes, I speak so fast that I am not understood. & ( & ) & ( & ) & ( & \\
\hline 10. Actually, I speak clearly all of the time and with adequate pronunciation. & ( & ) & ( & ) & ( & \\
\hline 11. I communicate my opinions and concepts coherently in a logical order. & ( & ) & ( & ) & ( & ) \\
\hline 12. Frequently, I use interesting, witty, or funny words when I speak. & ( & ) & ( & ) & ( & ) \\
\hline 13. When I express my ideas or thoughts, I do not use complete sentences. & ( & ) & ( & ) & ( & ) \\
\hline 14. When I speak in public, the volume of my voice is adequate in order to be heard by all participants. & ( & ) & ( & ) & ( & ) \\
\hline 15. Often, it pleases me to play with the sounds of words to make them rhyme. & ( & ) & ( & ) & ( & ) \\
\hline 16. During my frequent conversations, I experience constant interruptions or embarrassing pauses. & ( & ) & ( & ) & ( & ) \\
\hline 17. Frequently, in my conversations, the use of fillers predominates: esteee, $\mathrm{mmmm}$, ahhh, and, etc.?. & ( & ) & ( & ) & ( & ) \\
\hline 18. Often, I become blocked, and I lose the rhythm of the conversation with some people. & ( & ) & ( & ) & ( & ) \\
\hline 19. When I hear music, I follow the rhythm with my fingers. & ( & ) & ( & ) & ( & ) \\
\hline 20. I sing on key. & ( & ) & ( & ) & ( & ) \\
\hline 21. I can sing in harmony with other people. & ( & ) & ( & ) & ( & ) \\
\hline 22. I am happy when I use different animated and expressive intonations during my conversations. & ( & ) & ( & ) & ( & ) \\
\hline 23. I feel afraid, get the chills, or forget, and sweat when I present in front of a group of people. & ( & ) & ( & ) & ( & \\
\hline 24. In general, it is difficult for me to express my sentiments, wishes, or needs with gestures. & ( & ) & ( & ) & ( & \\
\hline 25. In general, when I am in a group, and I do not share the same opinions, I easily change my body posture. & ( & ) & ( & ) & ( & \\
\hline 26. I interpret the gestures and expressions of others easily. & ( & ) & ( & ) & ( & \\
\hline
\end{tabular}

